\title{
Memaknai Praktik Tradisi Ritual Masyarakat Muslim Sumenep
}

\author{
Achmad Mulyadi \\ Sekolah Tinggi Agama Islam Negeri (STAIN) Sumenep - Indonesia \\ Email: mulyadidik71@gmail.com
}

\begin{abstract}
THIS --paper seeks to uncover the meaning of tradition in the Muslim Ritual Sumenep Madura, which is understood as a local or popular ritual, associated with the determination of the calendar in Islam. This ritual, when expressed and understood in practice, is always based on the popularization of localized Islamic calendar names with certain insights and meanings. With deductive-inductive-explorative approach, this paper unravel three popular ritual practices of Sumenep Madura society that is Death, Peret Kandung and Sonnat Ritual. The practice of death ritual is intended as an effort (ikhtiyar) repent to Allah SWT. for self and al-marhum are prayed for, tying the ropes of brotherhood, and as an effective medium for the dakwah of Islam. While the practice of peret kandung and sonat ritual is the first pregnancy ritual for husband and wife who have entered the seventh month of pregnancy and continuation of ritual initiation in Sumenep kingdom is only for boys. Both are interpreted as a form of symbolization of purification and self-cleansing for children born safely and truly become pious children, boast of parents and all families and there is no obstacle in obedience and closer to Allah SWT
\end{abstract}

Keywords: Tradition, Ritual Practices and Islamic Calendar

\section{Pendahuluan}

Madura apabila dipandang dari suku maupun dari pola kehidupannya memiliki akar pengetahuan yang seolah tidak pernah habis untuk digali. Berbagai macam filosofi dari pewayangan, keyakinan, kepercayaan, tradisi, adat maupunpraktik-praktik lain selalu memiliki ciri dan sudut pandang yang luhur. Hakikat kemanusiaan ini dipahami sebagai tata cara dalam hidup yang mewujud bersama komponen kebijaksanaan sejak zaman leluhur. Dimensi ini memandang hidup yang dilimpahi berkah oleh suatu kekuatan yang menopang manusia.

Nilai-nilai Madura (madurologi) makin kental ketika bersentuhan dengan Islam sebagai agama rahmatan lil 'alamin. Madura pun akhirnya membentuk sejarah peradaban, dengan akulturasi budaya dan nilai-nilai yang bersatu-padu. Terlebih lagi, konsep ajaran dari Sunan Kalijaga yang terus menghidupkan nilai-nilai luhur dan melakukan pendekatan dengan cara tasawuf. Oleh karena itulah, Islam di Madura memiliki karakter khas. Ini tampak pada: 1) varian amalan (ritual)nya, 2) pemaknaan muslim Madura, khususnya Sumenep terhadap amalan (ritual).

Hasil penelitian Woodward dan Salim HS1, Mçler², Solikhin³ (2010), dan Ahyani4, menjadi salah satu bukti ilmiah dari karakter khas Islam Madura tersebut yang berusaha

\footnotetext{
${ }^{1}$ Woodward, Mark R. 1999. Islam Jawa: Kesalehan Normatif Versus Kebatinan (Normatif Piety and Mysticism) Terj. Hairus Salim HS. (Yogyakarta, LKiS, 2004), hlm. 15

${ }^{2}$ André Möller, "Ramadan in Java: The Joy and Jihad of Ritual Fasting", Vol. 20. Almqvist \& Wiksell International. 2005, hlm. 7

${ }^{3}$ Muhammad Solikhin, Misteri Bulan Suro Perspektif Islam Jawa. (Penerbit Narasi. 2010), hlm.10.

4 Shidqi Ahyani, "Islam Jawa: Varian Keagamaan Masyarakat Muslim dalam Tinjauan Antropologi.” Jurnal Salam, 2012, hlm. 15
} 
mengeksplorasi dimensi batin dan struktur sosial secara seimbang. Faktanya, memang Madura memiliki konsep-konsep keberhidupan terkait dengan dimensi transobjektif. Dalam buku Rites of Passage, Van Gennep mengungkapkan bahwa masyarakat memiliki tradisi/ritus unik terkait dengan daur hidup mereka, mulai dari lahir, kanak-kanak, remaja, nikah, hingga kematian. ${ }^{5}$

Dalam konteks ini, bahwa praktik ritual di seputar lingkaran hidup seseorang di Madura juga menjadi salah satu tradisi yang unik. Ritus ini dilakukan dengan dasar dan argumentasi yang jelas sehingga menjadi keyakinan di kalangan masyarakat, baik secara normatif (agama) maupun secara sosiologis.

Di Madura, tradisi di seputar praktik ritualitas dilakukan dengan cara yang unik, khas, dan seringkali berbeda antara satu tempat dengan tempat lain. Pada dasarnya, memang orang Islam Madura membentuk keyakinan dalam spiritualitas atas pengalaman batin. Oleh karena itu, apabila dicermati dengan seksama, praktik dan keyakinan dari masyarakat muslim Madura jika ditinjau darI antropologi budaya ini menarik untuk diteliti guna mengungkap makna ritualitas mereka secara mendalam.

\section{Islam Madura: Varian Islam Berbasis Tradisi Lokal}

Islam Madura merupakan salah satu varian Islam kultural yang ada di Indonesia setelah terjadinya dialektika antara Islam dengan budaya Madura. Proses dialektika tersebut pada gilirannya menghasilkan Islam Madura yang unik, khas, dan esoterik, dengan ragamnya tradisi-tradisi Madura yang sudah disisipi nilai-nilai Islam. Pada perkembangan selanjutnya, Islam dan tradisi Madura menjadi satu kesatuan yang tidak dapat dipisahkan meski masih dapat dibedakan satu sama lain.

Tradisi Madura yang Islami tersebut terpelihara kelestariannya hingga kini. Namun bukan berarti tanpa perubahan sama sekali. Di berbagai sisi, terdapat beberapa perubahan yang menunjukkan adanya dinamisasi Islam kultural yang tumbuh dan berkembang di Madura. Sebab, pada dasarnya perubahan memang suatu hal yang niscaya. Hal ini dapat dipahami lantaran tak ada yang stagnan di dunia ini. Perubahan senantiasa terjadi hampir dalam semua ruang kehidupan manusia, baik menyangkut persoalan politik, sosial, budaya, maupun ekonomi.

Dialog kreatif antara Islam dan budaya lokal tidaklah berarti "mengorbankan" Islam, dan menempatkan Islam kultural, sebagai hasil dari dialog tersebut, sebagai jenis Islam yang "rendahan" dan tidak bersesuaian dengan Islam yang "murni", yang ada dan berkembang di Jazirah Arab, ${ }^{6}$ tapi Islam kultural harus dilihat sebagai sebentuk varian Islam yang sudah berdialektika dengan realitas di mana Islam berada dan berkembang. Menjadi Islam, tidak harus menjadi Arab. Islam memang lahir di Arab, tetapi tidak hanya untuk bangsa Arab. Proyek Arabisme merupakan proyek politik yang berkedok purifikasi Islam, yang berusaha menjadikan Islam sebagai sesuatu yang

${ }^{5}$ Van Gennep. The Rites of Passage. (London: Pinguins, 2006), hlm. 203

6 Geertz misalnya, memandang bahwa sebenrnya Islam tidak mempunyai pengaruh signifikan dalam budaya Jawa. Islam yang disebarkan di Jawa, dinilainya sebagai Islam yang sudah ditumpulkan dan dibelokkan ke dalam mistik India . Islam yang demikian terputus dari pusat ortodoksinya di Jazirah Arab. Dengan demikian, Islam Jawa merupakan Islam sinkretis, yang sudah terkotori oleh budaya-budaya lokal yang bercorak Animisme dan Hinduisme-Budhisme. Clifford Geertz, Abangan, Santri, dan Priyayi dalam Masyarakat Jawa, (Jakarta: Pustaka Jaya, 1981), hlm. 170. 
tunggal dan seragam. ${ }^{7}$ Dalam pemahaman mereka, Islam kaffah adalah Islam yang ada dan berkembang di Arab, sehingga seluruh komunitas Islam harus mengikuti pola keberagamaan dan keyakinan yang mereka anut dan praktekkan. Tradisi dan adatistiadat setempat bagi mereka, merupakan bid'ah (sesat), yang dapat mencemarkan ajaran Islam yang sesungguhnya.

Hal ini tentu berbeda dengan pemahaman mayoritas ulama Indonesia yang lebih lentur dan bijak dalam memandang tradisi. Tradisi dan adat tidak lantas dipahami sebagai sesuatu yang sesat, selagi tidak bertentangan dengan ajaran Islam, dan Islam sebagai agama tampil secara kreatif berdialog dengan masyarakat setempat (lokal), berada dalam posisi yang menerima tradisi masyarakat, sekaligus memodifikasinya menjadi budaya baru yang dapat diterima oleh masyarakat setempat dan masih berada di dalam jalur Islam.

Islam masuk dan berkembang di Madura, sebagaimana juga di Jawa melalui transformasi kultural yang dilakukan oleh para penyebar Islam. Dengan demikian, Islam yang ada dan berkembang di Madura adalah Islam kultural, yang berbasis pada tradisi masyarakat. Tradisi-tradisi tersebut tetap lestari hingga kini. Hal ini memungkikan lantaran pola keberagamaan yang dianut oleh masyarakat Madura berbasiskan pada nilai-nilai tradisi, yang dalam hal ini dikembangkan oleh Nahdlatul Ulama. NU, bagi masyarakat Madura tidak hanya dipandang sebagai organisasi sosial keagamaan, tapi sebagai paham keagamaan itu sendiri. Bahkan, ada di antara mereka yang ketika ditanya tentang agama mereka, kemudian menjawab NU. Mereka tidak menjawab Islam lantaran dalam pemahaman sederhana mereka NU adalah Islam, dan Islam adalah NU.

Fanatisme ke-NU-an masyarakat Madura membawa efek ganda dalam pola keberagamaan mereka. Satu sisi, Islam kultural dapat terpelihara dengan baik dan bahkan terlembagakan sebagai bagian integral tradisi-tradisi NU. Namun di lain sisi, pada umumnya mereka ekslusif terhadap paham dan ajaran Islam selain NU.

Dalam melanggengkan tradisi, kiai juga peran signifikan, baik melalui NU sebagai organisasi, maupun melalui pesantrennya. Dalam organisasi NU, kiai memelihara berbagai tradisi Islami tersebut melalui kompolan-kompolan yang melibatkan masyarakat awam, maupun dalam upacara yang sifatnya kemasyarakatan. Melalui pesantren, kiai juga berperan dalam mewariskan dan mengajarkan tradisi-tradisi Islam tersebut kepada para santrinya melalui pembiasaan yang dilakukan secara terus menerus setiap hari. Hal ini dilakukan agar para santri dapat menggantikan gurunya dalam menjaga dan melestarikan tradisi tersebut agar tidak serta merta hilang dan dihapuskan oleh berbagai gerakan Islam puritan yang anti-tradisi lokal.

\section{Makna Kalender dalam Tradisi Ritual Masyarakat Muslim Sumenep}

${ }^{7}$ Ciri utama gerakan Islam ini adalah menjadikan Islam sebagai Ideologi Politik. Islam dijadikan dalih dan senjata politik untuk mendiskreditkan dan menyerang siapa pun yang dalam pandangan politik dan pemahamaan keagamaannya berbeda dari mereka. Jargon memperjuangkan Islam sebenarnya adalah memperjuangkan suatu agenda politik tertentu dengan menjadikan Islam sebagai kemasan dan senjata. Selain itu, dengan dalih memperjuangkan dan membela Islam, mereka berusaha keras menolak budaya dan tradisi yang selama ini telah menjadi bagian integral kehidupan bangsa Indonesia, malah berusaha menggantinya dengan budaya Timur Tengah. Dalam pandangan Gus Dur, hal ini terjadi lantaran mereka tidak mampu membedakan agama dari kultur yang tempat Islam diwahyukan. Baca, Abdurrahman Wahid, "Musuh dalam Selimut" sebuah pengantar pada buku Ilusi Negara Islam: Ekspansi Gerakan Islam Transnasional di Indonesia, (Jakarta: The Wahid Institute bekerjasama dengan Gerakan Bhinneka Tunggal Ika dan Maarif Institute, 2009), hlm. 19-20. 
Metode hisab Kalender ritual masyarakat Sumenep Madura menjadi pemikiran dan pola yang ditempatkan sebagai acuan perhitungan kalender, siklus peredaran Bulan dan Matahari itu logisnya harus bersifat eksak, dan nyatanya memang demikian. AlQur'an (ar-Rahman ayat 5) menegaskan: "Asy-syamsu wal-qamaru bihusban" (Matahari dan Bulan beredar dengan perhitungan), dan hasil penyelidikan ilmu pengetahuan membenarkan hal itu. Konsekuensi logisnya -karena peredaran Bulan dan Matahari bersifat eksak-adalah bahwa penyusunan kalender yang mengacu kepada peredaran kedua benda langit tersebut tentu bisa dilakukan dengan hisab atau perhitungan. Dari bangsa Arab, ilmu falak kemudian menyeberang ke Eropa, dibawa oleh bangsa Eropa yang menuntut ilmu pengetahuan di Spanyol seperti di Sevilla, Granada, dan Cordoba. Muncullah di Eropa Nicolas Copernicus (1473-1543), ahli ilmu falak dari Polandia yang mencetuskan teori heliosentris yang masih digunakan sampai sekarang. Selanjutnya, dengan ditemukannya teleskop oleh Galileo Galilei (1564-1642) yang menguatkan teori Nicolas Copernicus, ilmu falak kian maju lebih jauh lagi. Penguasaan ulama Islam terhadap ilmu falak telah memungkinkan mereka untuk melakukan penyusunan kalender berdasarkan hisab. Karena ini fenomena baru, maka ramailah perbincangan mengenai soal itu dari sudut hukum Islam (fiqh).

Di tengah kontroversi boleh tidaknya berpedoman pada hisab, sejumlah fuqaha seperti lbu Banna, Ibnu Syuraih, al-Qaffal, Qadi Abu Taib, Mutraf, lbnu Qutaibah, lbnu Muqatil ar-Razi, Ibnu Daqiqil 'Id, dan as-Subki, membolehkan penggunaan hisab dalam menentukan awal dan akhir Ramadan. Kendati sama rnengacu pada perhitungan siklus peredaran Bulan mengelilingi Bumi, tetapi dalam implementasinya dikenal adanya dua sistem hisab dalam penyusunan kalender qamariyah, yakni Hisab Urfi dan Hisab Hakiki. Hanya saja untuk kepentingan ritual masyarakat muslim Sumenep, hisab hakiki tidak banyak digunakan. Dalam sistem Hisab Urfi, kalender qamariyah disusun berdasarkan masa peredaraan rata-rata Bulan mengelilingi Bumi, yakni 29 hari 12 jam 44 menit 3 detik (masa yang berlalu di antara dua ijtimak yang berurutan, atau satu bulan Sinodis). Berdasarkan perhitungan ini, maka satu tahun (12 bulan) dihitung sama dengan 354 hari 8 jam 48 menit 36 detik (354 11/30 hari). Karena terdapat angka pecahan sebesar sebesar 11/30 hari, maka untuk menghilangkannya sistem ini membuat siklus 30 tahunan dalam kalender qamariyah yang terdiri dari 19 tahun Basitah (354 hari) dan 11 tahun Kabisat (355 hari). Tahun-tahun Kabisat (tahun panjang) dalam siklus 30 tahun tersebut jatuh pada urutan ke 2, 5, 7, 10, 13, 16, 18, 21, 24, 26, 29. Umur bulan dalam sistem ini dibikin tetap, yakni 30 hari untuk bulan-bulan ganjil dan 29 hari untuk bulan-bulan genap (kecuali bulan ke 12 pada tahun-tahun Kabisat berumur 30 hari).

Dengan sistem ini, awal bulan-bulan qamariyah di segenap belahan Bumi akan selalu jatuh pada hari yang sama. Tetapi karena mengesampingkan variabel penampakan hilal, maka -dalam kerangka penentuan waktu untuk pelaksanaan hukum syari'at- sistem ini tidak banyak dianut oleh kaum muslimin.Dari konteks di atas, hisab 'urfi dapat dikriteriakan antara lain: (1) Bulan qomariyah ditentukan berdasarkan umur rata-rata bulan sehingga dalam setahun qomariyah umur setiap bulannya dibuat bervariasi 29 dan 30 hari; (2) Bulan bernomor ganjil yaitu mulai Muharram berjumlah 30 hari dan bulan bernomor genap yaitu mulai Shafar berumur 29 hari. Tetapi khusus bulan Zulhijjah (bulan 12) pada tahun kabisat komariyah berumur 30 hari; (3) Tahun kabisat qomariyah memiliki siklus 30 tahun dimana didalamnya terdapat 11 tahun yang disebut tahun kabisat (panjang) memiliki 355 hari, dan 19 tahun yang disebut basithah (pendek) memiliki 354 hari; (4) Tahun kabisat ini terdapat pada tahun ke 2, 5, 7, 10, 13, 16, 18, 21, 24, 26 dan ke 29 dari keseluruhan siklus kabisat selama 30 tahun; (5) Dengan demikian kalau 
dirata-rata maka periode umur bulan (bulan sinodis/lunasi) menurut Hisab Urfi adalah $(11 \times 355$ hari $)+(19 \times 354$ hari $):(12 \times 30$ tahun $)=29$ hari 12 jam 44 menit (menurut hitungan astronomis: 29 hari 12 jam 44 menit 2,88 detik); dan (6) walau terlihat sudah cukup teliti namun yang jadi masalah adalah aturan 29 dan 30 serta aturan kabisat tidak menujukkan posisi bulan yang sebenarnya, akan tetapi, hanya pendekatan.

Metode taqribi menentukan derajat ketinggian bulan paska ijtimak berdasarkan perhitungan yang sifatnya "kurang-lebih", yakni membagi dua selisih waktu antara saat ijtimak dengan saat terbenam Matahari. Metoda hisab Sullamun Nayyirain, Fathur Rauf al-Mannan dan sejenisnya dipandang masuk dalam kategori ini. Metode ini memiliki ciriciri sebagaimana berikut, yaitu, pertama, metode hisab ini sudah menggunakan kaidahkaidah astronomis dan matematik, akan tetapi rumus-rumusnya masih sederhana sehingga hasilnya kurang teliti, kedua, hasil hisab taqribi akan sangat mudah dikenali saat penentuan ijtimak dan tinggi hilal menjelang 1 Ramadhan, Syawal dan Zulhijjah yaitu terlihatnya selisih yang cukup besar terhadap hitungan astronomis modern, ketiga, beberapa kitab falak yang berkembang di Indonesia yang masuk dalam kategori Hisab Taqribi misalnya; Sullam al Nayyirain, Ittifaq Dzatil Bainy, Fat al Raufal Manan, Al Qawaid al Falakiyah. Dari dua sistem tersebut, perhitungan untuk penentuan kalender Madura merupakan perpaduan bahkan cenderung lebih disederhanakan yaitu menambah 5 hari dari hari yang telah digunakan, seperti awal puasa $1432 \mathrm{H}$ jatuh hari senin, maka awal puasa $1433 \mathrm{H}$ akan jatuh pada hari Jumat.

Penentuan kalender tersebut sangat berkait erat dengan tradisi ritual yang masyarakat Sumenep Madura lakukan. Tradisi ini banyak melibatkan kiai dan komunitas santri di dalamnya bahkan membentuk kalender ritual tersendiri yang bersifat kultural. Kalender ritual yang berwarna kultural ini dapat dilihat dari penamaan sekaligus pemaknaan bulan dalam kalender Madura. Apabila dibandingkan dengan sumber aslinya dalam khazanah Islam, penamaan dan pemaknaan kalender ini sangatlah khas dan unik. Dalam khazanah Islam, nama dan makna kalender Islam yang dikenal oleh masyarakat Arab (proyek arabisme) seperti bulan Muharram diartikan Haram (haram berperang), Safar diartikan Perjalanan (musim para kabilah berdagang keluar daerah, Rabi' al-awwal diartikan awal Musim Semi.- Rabi' al-akhir diartikan akhir Musim Semi. Jumada al-awal diartikan awal Musim Kering/mati (tumbuhan), Jumada al-akhir diartikan akhir Musim kering/mati (tumbuhan), Rajab diartikan Menghormati (persiapan bekal (fisik \& mental) menuju Ramadhan), Sya'ban diartikan Berpencar (berpencar mencari mata air, Ramadhan diartikan bulan diturunkan-NYA ayat-ayat al-Qur'an, Syawal diartikan Membawa (musim hewan berkembang biak (betina membawa isi), Dzu al-Qa'idah diartikan pemilik sikap duduk/tidak berdiri (masa tenang, tidak berperang, Dzu al-Hijjah diartikan pemilik masa Hajj/Haji (musim Haji). Dengan demikian, dari penamaan dan pemaknaan dua kalender tersebut menemukan istilah dan makna yang berbeda, walaupun sebenarnya dalam kalender Madura sudah banyak mengalami inkulturasi dengan tradisi masyarakat Sumenep dan dipengaruhi oleh kalender Jawa Islam karena itu memiliki kemiripan.

Kalender ritual yang berwarna kultural ini, dinamai dan dimaknai, pertama, bulan Sora bermakna suci sebagai simbol manusia itu dibekal fitrah kesucian atau potensi manusia untuk berbuat baik. ${ }^{8}$ Untuk itu, bulan tersebut disimbolisasi dengan warna putih, yang diformulasi dengan pembuatan bubur putih, kedua, bulan Sappar sebagai kelanjutan bulan yang pertama, yaitu walaupun manusia memiliki fitrah suci, akan tatapi

${ }^{8}$ Dapat dibandingkan dengan artikel yang ditulis oleh Monica Dian dan Mojiono, An Analysis Of Symbolism On Satu Suro In Kraton Yogyakarta, Jurnal Ilmiah Bahasa dan Sastra, ISSN: 23557083, Volume 2 no. 22015 
manusia berpotensi berbuat jelek, kaerena itu perlu dikendalikan dengan simbolisasi warna merah, yang diformulasi dengan pembuatan Tajin Sappar yakni Tajin warna putih dan merah, ketiga, bulan Molod bermakna bulan kelahiran Nabi Muhammad Saw, karena itu, masyarakat Sumenep memperingatinya dengan bermacam kegiatan seperti dibe'en, keempat, kelima keenam dan ketujuh, bulan Rasol, Jumadil Awal, Jumadil Akher dan Rajab kurang mendapat perhatian khusus masyarakat Sumenep sehingga pada bulan-bulan tersebut diyakini sebagai bulan yang bebas melakukan aktifitas apapun termasuk tasyakuran, perayaan dan lain-lain. Kedelapan, bulan Rebbe yang berarti memberikan sadaqah kepada orang lain. Kesembilan, bulan Poasa bermakna menahan untuk tidak makan dan minum mulai terbit fajar sampai terbenam matahari dengan dibumbuhi bacaan alqur'an, maupun amalan-amalan sunnah lainnya. Kesepuluh, bulan Sabel bermakna bulan saling maaf-memaafkan sebagai penyempurna dan memperbaiki hubungan antar manusia. Kesebelas, bulan Takepe' bermakna bulan sempit atau tidak luas karena berada diantara bulan Sabel dan Dzulhijjah. Dan keduabelas, bulan Reaje bulan pengorbanan dan harapan.

\section{Praktik Ritual Masyarakat Muslim Sumenep}

Kalender ritual masyarakat Muslim Sumenep Madura merupakan refleksi keagamaan dalam bentuk praktik ritual, bahwa ritual adalah sebuah upacara keagamaan, tidak terkecuali dalam Islam. Bahkan Islam sangat menekankan pada aspek ritual. Begitu penting aspek ritual ini, upaya memberikan penjelasan komprehensif dan kontruktif dari makna-makna yang sebenarnya dari praktik ritualitas tersebut sangat urgen dilakukan. Praktik ritual dalam Islam dapat dibedakan menjadi dua macam, yaitu ritual yang ideal (ritual 'resmi') dan ritual lokal yang berkembang dibeberapa masyarakat tertentu (ritual 'lokal' atau 'popular').

Pada realitasnya, ritual lokal masyarakat Muslim Sumenep Madura sangat berkait dengan konsep hari, tanggal dan bulan dalam sebuah kalender. Di antara praktik ritualritual lokal tersebut ${ }^{9}$, antara lain:

\section{a. Ritual Kematian}

Ritual kematian di masyarakat dikenal dengan tradisi tahlilan. Tradisi ini merupakan upaya mendoakan orang yang sudah meninggal agar arwahnya bisa tenang di alam barzah. Dalam upacara ini, orang yang hadir mendoakan orang yang sudah meninggal dengan membaca yasin, tahlil, atau dzikir-dzikir lain yang mana pahalanya dikhususkan pada orang yang meninggal tersebut. Selain itu, pihak keluarga juga memberikan shadaqah berupa suguhan makanan bagi para pelayat yang mendoakan, dengan harapan agar pahala shadaqah tersebut juga sampai pada arwah orang yang meninggal tersebut.

Dengan dilaksanakannya upacara yang sarat dengan doa-doa ini diharapkan dosadosa yang sudah meninggal diampuni dan siksanya diringankan oleh Allah. Yang menarik dari tradisi ini adalah penentuan waktu ritual kalendernya yang dilakukan

${ }^{9}$ Dalam masyarakat Jawa dikenal dengan keragaman tradisi lokalnya yang terkait dengan lingkaran hidup sampai upacara keagamaan yang dapat dibedakan menjadi empat kategori, yaitu: pertama, ritus lingkaran hidup, kedua, upacara tolak bala, ketiga, upacara hari-hari Islam, dan keempat, upacara hari-hari baik. Lihat, Nur Syam, Mazhab-Mazhab Antropologi, (Yogyakarta: LKiS, 2011), hlm. 121.. 
tidak hanya sekali saat hari pertama kematian itu sendiri. ${ }^{10}$ Ritual ini kematian masih dilanjutkan dengan $l o^{\prime}$ tello' (hari ketiga), to' petto' (hari ketujuh), $p a^{\prime}$ polo (hari keempat puluh), nyatos (hari keseratus), nyataon (satu tahun setelah kematian) dan nyaebu (hari keseribu dari kematian). Hampir tidak ada perubahan dan perbedaan berarti dalam setiap sesi upacara kematian tersebut. Dalam setiap upacara tersebut sarat dengan tahlil, dzikir-dzikir, dan yasin. Hanya saja, bedanya, untuk $l o^{\prime}$ tello' dan to' petto', pihak keluarga tidak mengundang orang lain untuk mendoakan, tapi sebaliknya orang-orang yang datang melayat untuk mendoakan orang yang sudah meninggal tersebut. Berbeda dari itu, untuk $p a^{\prime}$ polo dan seterusnya, justru pihak keluarga yang mengundang orangorang untuk mendoakan orang yang sudah meninggal, sesuai dengan kemampuan ekonomi keluarganya. Perbedaan lainnya terletak pada upacara nyataon, untuk memperingati satu tahun setelah meninggalnya seseorang. Bahkan dalam komunitas kiai, apabila yang meninggal adalah kiai atau orang yang shaleh, maka peringatan tahunan (haul) untuk selanjutnya diperingati setiap tahun, tidak hanya sekali sebagaimana yang terjadi dalam upacara kematian dalam masyarakat pedesaan. Hal ini dilakukan tidak untuk mendoakan kiai agar tentram di alam sana, tapi yang terpenting agar orang yang hidup, yang mendoakan tersebut dapat menerima barokah dari orang yang sudah meninggal tersebut. Namun demikian, tradisi ini bukan tanpa kritikan. Masih ada sekelompok masyarakat yang menuding waktu kalender ritual kematian ini sebagai bid'ah dan merupakan tradisi nenek moyang yang tidak ada dasar syar'inya. Terlepas dari perdebatan tersebut para ulama tetap sepakat untuk terus memelihara pelaksanaan tradisi tahlil tersebut berdasarkan kokohnya dalil-dalil dari Hadits, AlQur'an, serta kitab-kitab klasik yang menguatkannya. Dan tak sedikit manfaat yang dirasakan dalam pelaksanaan tahlil tersebut, diantaranya adalah sebagai ikhtiyar (usaha) bertaubat kepada Allah untuk diri sendiri dan saudara yang telah meninggal, mengikat tali persaudaraan antara yang hidup maupun yang telah meninggal, mengingat bahwa setelah kehidupan selalu ada kematian, mengisi rohani, serta media yang efektif untuk dakwah islamiyah.

\section{b. Ritual Peret Kandung}

Peret Kandung merupakan ritual kehamilan pertama bagi suami-istri yang memasuki bulan ketujuh. Dalam upacara ini, suami-istri dimandikan di tengah halaman rumah dengan menggunakan air kembang tujuh rupa, sebagai sebentuk simbolisasi penyucian diri, agar anak yang lahir nantinya selamat dan benar-benar menjadi anak sholeh, yang membanggakan orang tua. Setelah mandi kembang tujuh rupa, pasangan suami istri tersebut harus masuk ke kamar rumahnya sembari menggendong buah kelapa, yang sudah diberi nama Maryam dan Yusuf. Hal ini juga merupakan simbolisasi agar apabila anaknya kelak lahir, bila perempuan akan secantik dan sebaik maryam dan bila laki-laki akan setampan wajahnya yusuf. Terlepas dari itu, dalam tradisi peret kandung ini sarat dengan doa-doa dan pembacaan ayat suci. Kyai, diundang untuk memimpin doa dan membaca ayat suci al-Qur'an. Surat-surat yang biasa dibaca adalah surat Yusuf, Maryam, Yasin, Muhammad dan juga memperbanyak membaca shalawat pada Nabi Muhammad Saw agar mendapat syafaat. Yang menarik dikaji dalam tradisi ini adalah penentuan waktu ritual kalendernya yaitu tujuh bulan, mengapa tidak satu bulan, atau empat bulan. Penentuan waktu dengan bulan ketujuh karena waktu tujuh bulan adalah

${ }^{10}$ Suwito, Agus Sriyanto dan Arif Hidayat, Tradisi dan Ritual Kematian Wong Islam Jawa, dalam Jurnal Kebudayaan Islam, ISSN: 16936736, Vol. 13 no. 2 Juli-Desember 2015. 
waktu dimana si janin sudah sempurna baik berkait dengan penentuan takdir, peniupan roh dan kelengkapan fisik sehingga sudah siap dan sempuna untuk dilahirkan.

\section{c. Ritual Sonat}

Bagi masyarakat Indonesia saat ini, praktik sunat dinilai sebagai peninggalan tradisi kebudayaan masa lampau. Sayangnya, tidak ada pendokumentasian bagaimana praktik ini dilakukan pada masa lampau sehingga asal-usulnya sangat sulit untuk diketahui. Meski demikian, secara historis praktik sunat sudah dilakukan 'jauh sebelum masjid, gereja, dan kerajaan Jawa itu ada'. Ini mengisyaratkan bahwa kemungkinan sunat berasal dari praktik animisme-dinarnisme di kalangan masyarakat setempat. Indikasi mengenai hal ini dapat dicermati dalarn cerita mitologi Jawa yang menggambarkan sunat sebagai ritual yang menyimbolkan pembebasan diri dari Betara Kala, dewa pemangsa manusia.

Pendokumentasian praktik sunat di Indonesia yang lebih lengkap adalah setelah masuknya Islam ke Indonesia. Mulai periode ini, sunat cenderung diberi konotasi 'mengislamkan'. Munculnya konotasi ini berkaitan dengan strategi penyiaran agama Islam yang berpusat di tanah Jawa oleh Walisongo (sembilan wali). Agar lebih mudah diterima oleh masyarakat setempat, mereka menggunakan cara memberi kemasan baru pada praktik sunat yang berakar pada kepercayaan asli masyarakat, yaitu animismedinamisme. Karena Islam hanya merupakan kemasan, maka sense yang terkandung dalam istilah ngeslamke lebih menunjuk pada makna sosial "menjadi bagian dari komunitas Islam" semata daripada makna religius yang lebih mendalam "menjadi muslim sejati", Latar belakang ini pula yang menyebabkan praktik sunat yang berkembang di Jawa tidak sepenuhnya tercabut dari akar kepercayaan animismedinarnisme. Terbukti di kalangan kaum abangan, sunat tetap dilihat sebagai salah satu siklus selamatan, sebelum ritual inti masyarakat jawa berupa upacara makan bersama, pembakaran kemenyan (unsur animisme-dinamisme), dan pembacaan doa shalawat (unsur Islam), yang bertujuan untuk menjaga keteraturan dankeselamatan hidup bersama. Perpaduan unsur-unsur kepercayaan yang muncul dalam ritual selamatan ini sekaligus mencerminkan pandangan dunia orang Jawa yang berakar pada kepercayaan mistik Jawa, yaitu sebuah bentuk sinkretisme kepercayaan yang mencakup animismedinamisme, Hindu, Budha, dan Islam. Jadi, dapat disimpulkan bahwa konotasi ngeslamke (mengislamkan) pada praktik sunat tidak bisa dilepaskan dari kerangka budaya Jawa yang bersifat sinkretis ini.

Pada saat ini, terdapat perbedaan konteks yang melatarbelakangi praktik sunat di Jawa dan Madura yang disebabkan oleh adanya perkembangan budaya Jawa sinkretis yang berbeda di kedua daerah tersebut. Di satu sisi, praktik sunat di Jawa lebih mengakar pada budaya Jawa sinkretis sebagaimana didukung oleh kerajaan Yogyakarta yang hingga saat ini masih bertahan sebagai penjaga budaya. Di sisi lain, praktik sunat di Madura lebih didominasi oleh nuansa Islam 'murni', yaitu Islam yang berkiblat pada tradisi Arab. Hal ini disebabkan oleh pengaruh budaya Jawa sinkretis yang dibawa oleh kebudayaan Mataram yang berpusat di Jawa pada masa lampau hanya bisa mencapai kalangan bangsawan Madura di pedalaman. Oleh karena itu, perkembangan masyarakat Madura secara umum lebih didorninasi pengaruh unsur kepercayaan Islam 'murni' yang dibawa oleh pedagang dari Arab, Persia, dan Gujarat melalui daerah pesisir.

Perbedaan konteks yang melatar belakangi praktik sunat di Jawa dan Madura di atas secara khusus juga ikut mempengaruhi kecenderungan praktik sunat perempuan. 
Di kalangan masyarakat Jawa, sunat khususnya bagi perempuan cenderung mengakar pada budaya Jawa sinkretis seperti tercermin melalui istilah lokal tetesan yang dikenal sebagai salah satu dari serangkaian ritual di lingkungan kerajaan Yogyakarta. Sementara itu, rangkaian ritual inisiasi lainnya meliputi upacara kelahiran (brokohan), pemberian nama (selapanan), pertama kali menginjak tanah (tedhak siten), menjelang akil baligh (tetesan untuk perempuan, supitan/tetakan untuk laki-laki), haid pertama (tarapan untuk perempuan), perkawinan, dan kematian. Selain dipraktikkan di lingkungan kerajaan, rangkaian upacara adat ini juga dipraktikkan di daerah perdesaan dengan pelaksanaan yang lebih sederhana disertai dengan ritual selamatan.

Bagi sebagian masyarakat Jawa pemeluk agama Islam, sunat perempuan lebih dilihat sebagai bentuk ibadah agama Islam, tanpa perlu sungguh-sungguh mempraktikkannya. Artinya, budaya Jawa sinkretis hingga dewasa ini masih cukup memengaruhi sikap pragmatis pemeluk agarna Islam terhadap praktik sunat perempuan. Di kalangan Islam modern (Muhammadiyah), Islam tradisional (Nahdlatul Ulama), dan Islam fundamental misalnya, terjadi perbedaan pendapat mengenai hukum khitan perempuan, antara wajib dan sunnah. Meski demikian, tidak satu pun dari kelompok-kelompok tersebut yang benar-benar memberikan sanksi bagi perempuan Muslim yang tidak melaksanakannya.

Di kalangan masyarakat Madura, sunat perempuan seperti halnya sunat laki-laki dikenal melalui istilah lokal sonat (bhs. Madura) atau khitan (bhs. Arab). Praktik Sonat ini tidak diperoleh petunjuk yang secara historis dapat menjelaskan keberadaan praktik sunat perempuan di Madura sebagai tradisi budaya Jawa sinkretis, sungguh pun keberadaan priayi Madura di lingkungan kerajaan Sumenep rnasih diperhitungkan dalam kehidupan masyarakat setempat hingga saat ini, yang mengindikasikan bahwa sunat sebagai ritual inisiasi di lingkungan kerajaan Sumenep hanya untuk anak laki-laki, yang sekaligus berlaku sebagai ritual dakwah islamisasi. Biasanya ritual ini dilakukan dengan mengarak anak laki-laki yang baru saja disunat di atas kuda. Tidak dikenalnya lagi praktik sunat perempuan yang mengakar pada tradisi budaya Jawa sinkretis di Madura ini kemungkinan disebabkan oleh tradisi tetesan yang dibawa oleh kerajaan Jawa ke Madura pada masa lampau tidak cukup terjaga oleh kerajaan Sumenep sebagai pusat budaya Jawa sinkretis di Madura. Dengan demikian, sunat perempuan di Madura dalarn perkembangannya lebih dikaitkan dengan tradisi khitan sebagai unsur kepercayaan Islam 'mumi' yang tampaknya lebih kuat memengaruhi masyarakat setempat.

Praktik sonat yang didorong oleh alasan 'agama' atau 'tradisi' di atas sebenamya memiliki keterlibatan yang lebih mendalam sehubungan dengan makna sunat itu sendiri bagi masyarakat Jawa dan Madura. Alasan 'tradisi' melibatkan makna mistis sunat yang terkait dengan ritual pernurnian bagi penganut kejawen atau kepercayaan mistik Jawa dalam kaitannya dengan siklus kehidupan. Pemaknaan seperti ini berakar pada pandangan kosmologi Jawa yang melihat dunia ini sebagai sebuah keteraturan dan keteraturan ini setiap saat dapat terancam atau terganggu oleh adanya kekuatan jahat dari luar. Ancaman atau gangguan ini tercermin melalui konsep sukerto, yaitu kesialan atau kekotoran yang secara kodrati dibawa oleh individu sejak ia dilahirkan. Untuk membebaskan individu dari segala kekuatan jahat, sukerto harus dihambat melalui ritual pemurnian diri. Ritual ini biasanya dilaksanakan pada saat-saat krisis kehidupan individu, misalnya kelahiran, peralihan masa kanak-kanak menuju kedewasaan, perkawinan, dan kematian. Sunat, dalam hal ini, merupakan sebuah ritual yang menyimbolkan pemurnian individu ketika memasuki saat krisis dari kanak-kanak menuju kedewasaan. Dari konteks inilah, penentuan waktu ritual sonat dalam kalender 
Madura dapat dipahami yaitu antara umur 7-8 tahun., hanya bagi perempuan memiliki waktu dan makna tersendiri yaitu umur 7 hari atau 35 hari, di samping bermakna menjaga sisi privat (kerahasiaan), juga untuk kepentingan kesehatan reproduksi perempuan itu sendiri.

Adanya kalender ritual keagamaan menjadi tradisi lokal masyarakat muslim Sumenep dan juga akan selalu berhadapan dengan tantangan modernitas. Beberapa tradisi lokal yang peneliti hadirkan dalam kajian di atas, hingga saat ini masih dipraktekkan dalam kehidupan masyarakat Madura. Tradisi-tradisi tersebut masih tetap dipelihara dan dilestarikan hingga saat ini sebagai upaya untuk menjaga khazanah lokal agar tidak hilang ditelan sejarah. Namun demikian, tradisi-tradisi tersebut tidak berarti statis dan tidak berubah sama sekali. Di sana sini, ada banyak perubahan yang terjadi dalam setiap tradisi di atas, sebagai bagian dari dinamika kultural yang tak terhindarkan.

Hal ini dapat dipahami lantaran tradisi pada prinsipnya memang bukanlah suatu hal yang stagnan. Ia diwariskan dari satu generasi ke generasi selanjutnya dalam situasi, kondisi dan waktu yang berbeda dengan sebelumnya. Akibatnya, akan ada perubahanperubahan baik dalam sakala kecil atau besar. Perubahan-perubahan ini sedikitnya dipengaruhi oleh dua hal mendasar, pertama, tuntutan modernitas yang mendesak, sehingga diniscayakan adanya penyesuaian-penyeseuaian dalam tradisi itu sendiri. Kedua, tidak sempurnanya proses pearisan tradisi dari generasi tua kepada generasi selanjutnya. Hal ini terjadi lantaran kurangnya minat generasi muda untuk mempelajari dan mempraktekkan nilai-nilai tradisi tersebut. Namun demikian, yang perlu dipahami di sini, dalam proses pewarisan, memang ada hubungan dialektik yang terjadi terus menerus antara tradisi, masyarakat dan zaman di mana proses itu berlangsung. Antar ketiganya meniscayakan adanya dialog yang terjadi secara dinamis sehingga menghasilkan nilai-nilai dan tradisi baru yang disepakati bersama, yang sesuai dengan zaman.

Dengan demikian, perubahan, dalam derajat tertentu, merupakan keniscayaan yang tidak terhindarkan. Kaitannya dengan dua tradisi di atas, perubahan banyak terjadi dalam simbol-simbol yang mengandung kearifan lokal di dalamnya. Dalam upacara kematian misalnya, pada mulanya, tahlil tidak akan pernah dimulai sebelum ada pembakaran kemenyan lebih dahulu. Namun saat ini, pembakaran kemenyan tidak lagi menjadi keharusan dalam setiap upacara kematian. Upacara akan langsung dimulai, jika undangan (baca: pelayat) sudah banyak dan sang kiai yang memimpin jalannya upacara sudah hadir di tengah-tengah masyarakat. Dalam tradisi peret kandung, ritual mandi kembang tujuh rupa dan menggendong kelapa pun sudah mulai ditinggalkan. Pada sebagian masyarakat, upacara peret kandung dicukupkan dengan mengundang orang untuk mengaji bersama demi keselamatan anak yang ada dalam kandungan dan juga ibunya yang hamil tersebut. Selain itu, di kalangan kiai dan komunitas santri, peret kandung tidak hanya dilakukan pada bulan ketujuh dari kehamilan, tapi juga pada bulan keempat. Namun perbedaannya dengan peret kandung bulan ketujuh, pada bulan keempat ini tidak ada ritual yang diambil kearifan lokal. Kecuali itu, hanya mengundang kiai dan masyarakat untuk berdoa untuk keselamatan kehamilan, ibu, dan juga agar anak yang dilahirkan menjadi anak yang shaleh. Sebab, pada bulan keempat inilah Allah memberikan ruh pada bayi yang ada dalam kandungan, berikut dengan penentuan rizki, jodoh, dan kematiannya. Dengan doa bersama ini, diharapkan anak yang akan lahir kelak mendapat takdir yang baik dari Allah swt.

Perubahan-perubahan tersebut tidak terlepas dari peran kiai di dalamnya. Ada dua cara yang dilakukan kiai dalam hal ini. Pertama, "pembiaran". Dalam hal ini, kiai 
membiarkan terjadinya kekuranglengkapan dalam suatu upacara. Semisal, tidak adanya kemenyan, tidak lantas menggagalkan terhadap jalannnya upacara, tapi upacara tetap dilanjutkan meski tanpa adanya kemenyan. Pembiaran yang demikian pada perkembangannya mengkonstruk pemahaman masyarakat bahwa kemenyan bukan suatu hal yang pokok dalam pelaksanaan upacara. Pemahaman yang demikian pada akhirnya akan dibiasakan oleh masyarakat sehingga tradisi membakar kemenyan sebelum acara dimulai tidak lagi digunakan oleh masyarakat. Kedua, teladan dan pembiasaan. Kiai sebagai figur ideal panutan umat, harus memberikan teladan yang baik yang dapat dicontoh. Apa yang dilakukan oleh kiai, kaitannya dengan tradisi, merupakan "kebenaran" yang harus diikuti. Dalam tradisi peret kandung misalnya, jika keluarga besar kiai memulai tradisi baru berupa upacara peret kandung sejak bulan keempat, maka masyarakat juga akan mengikuti tradisi ini. Sebab, kiai dipandang memiliki otoritas dalam hal ini. Dengan demikian peran kiai dalam hal ini adalah sebagai media transformasi. Kiai dengan caranya sendiri telah melakukan trasnformasi kultural secara dinamis dalam masyarakat. Ini dilakukan agar dinamisasi Islam kultural dapat terjaga dengan baik.

\section{Simpulan}

Tradisi ritualitas masyarakat muslim Sumenep, pertama, secara metodologis, penentuan kalender muslim Sumenep didasarkan pada hisab 'urfi, yang penentuannya hanya berdasarkan data tetap dengan cara menambah lima pada hari yang sudah diketahui, kedua, nama-nama bulan dalam kalender Madura dalam pandangan masyarakat muslim Sumenep memiliki makna tersendiri, berbeda sama sekali dengan kalender Jawa atau Islam. Namun demikian, masyarakat Sumenep berpandangan bahwa semua bulan baik, hanya saja diantara bulan tersebut ada waktu baik dan ada waktu jelek dan dalam penetuan waktunya dikenal tiga konsep yang berkembang, yaitu $\mathrm{Na}^{\prime}$ as Nabi, Buko Mate, dan Panage'en, ketiga, praktik ritual masyarakat Sumenep Madura terkategori sebagai ritual 'lokal' atau 'popular'. Ritual yang dipahami sebagai upacara keagamaan, sangatlah berkait dengan konsep hari, tanggal dan bulan dalam sebuah kalender, baik pada ritual kematian, ritual peret kandung dan ritual sonat dengan symbol dan makna yang diharapkan berguna dalam kehidupan beragama dan bermasyarakat.

\section{Daftar Pustaka}

Anonim. 1965. Encyclopaedia Britanica, London; William Benton Publisher.

Geertz, Clifford. 1981. Abangan, Santri, dan Priyayi dalam Masyarakat Jawa. Jakarta: Pustaka Jaya.

Gennep, Van. 2006. The Rites of Passage. London: Pinguins,

Lévi-Strauss, Claude. 2005. Antropologi Struktural (Anthropologie Structurale). Terj. Ninik Rochani Sjams. Yogyakarta: Kreasi Wacana.

Möller, André. 2005. Ramadan in Java: The Joy and Jihad of Ritual Fasting. Vol. 20. Almqvist \& Wiksell International. 
Monica Dian dan Mojiono. 2005. An Analysis Of Symbolism On Satu Suro In Kraton Yogyakarta. Jurnal Ilmiah Bahasa dan Sastra, ISSN: 23557083, Volume 2 No. 2 Tahun 2015.

Nur, Muhammad. 1983. Pedoman Awal Bulan Qamariyah. Jakarta: Depag RI.

Nur Syam. 2011. Mazhab-Mazhab Antropologi, Yogyakarta: LKiS, 2011

Salam, Nawawi. 2004. Rukyat Hiisab di Kalangan NU-Muhammadiyah, Surabaya: Diantana

Shidqi Ahyani. 2012. Islam Jawa: Varian Keagamaan Masyarakat Muslim dalam Tinjauan Antropologi. Jurnal Salam

Solikhin, Muhammad. 2010. Misteri Bulan Suro Perspektif Islam Jawa. Jakarta: Penerbit Narasi.

Suwito, Agus Sriyanto dan Arif Hidayat. 2015. Tradisi dan Ritual Kematian Wong Islam Jawa, dalam Jurnal Kebudayaan Islam, ISSN: 16936736, Vol. 13 No. 2 JuliDesember 2015.

Wahid, Abdurrahman. 2009. Musuh dalam Selimut sebuah Pengantar pada Buku Ilusi Negara Islam: Ekspansi Gerakan Islam Transnasional di Indonesia, Jakarta: The Wahid Institute bekerjasama dengan Gerakan Bhinneka Tunggal Ika dan Maarif Institute.

Woodward, Mark R. 1999. Islam Jawa: Kesalehan Normatif Versus Kebatinan (Normatif Piety and Mysticism). Terj. Hairus Salim HS. Yogyakarta: LKiS. 